\title{
The Readiness of Parents in Positioning Themselves as Teachers during the Pandemic (Case Study of Parents of Temporary Private Workers in Tenda Sub-district, Langke Rembong District)
}

\author{
Nendi $\mathrm{F}^{1}$, Tamur $\mathrm{M}^{2}$, Kurnila V.S., ${ }^{3}$, Ningsi G.P., ${ }^{4}$ and Mulu $\mathrm{H}^{5}$ \\ $1,2,3,4,5$ Universitas Katolik Indonesia Santu Paulus Ruteng, Indonesia
}

\{ransiskusnendi@gmail.com $\left.{ }^{1}\right\}$

\begin{abstract}
This study aimed to reveal the readiness of parents to position themselves as teachers for children during the pandemic. This research was conducted in the Sub-district of Tenda, Langke Rembong District, Manggarai Regency. The research subjects consisted of parents of elementary school students who worked in private and non-permanent institutions. The subjects were 10 people who represented hired and non-permanent or temporary workers. From this subject, 5 people represented private workers, and 5 others represented temporary workers. The data were collected through direct interviews with the research subjects. The results showed that the parents experienced limitations in guiding their children. These limitations include (1) difficulty in managing time to complete office work and time to guide children. (2) difficulties in dealing with children, especially when children are always not ready to be guided by their parents. (3) parents are overwhelmed by student difficulties in completing school assignments. (4) parents have difficulty in motivating and providing reinforcement for children's interest in learning. (5) parents still experience difficulties in directing their children to create children's good characteristics. (6) children prefer to play than complete their tasks. (7) parents who are not accustomed to guiding children find it overwhelming in guiding children.
\end{abstract}

Keywords: Readiness; parents; elementary students; pandemic

\section{Introduction}

The Covid-19 disease, which is easily contagious and its rapid spread has resulted in the emergence of new policies in all aspects of life as a nation-state, including the world of education in Indonesia. In Indonesia, education policy during the Covid-19 pandemic was to "prioritize the health and safety of students, educators, administrative staffs, families and the general public, as well as consider the growth and development of students and psychosocial conditions in an effort to fulfill educational services during the Covid-19 pandemic" (Ministry of Education and Culture, 2020).

The closure of these educational institutions then culminated in policies of learning from home, teaching from home, or working from home [1]. Similar policies resulted in the emergence of "a tsunami of online learning has occurred almost all over the world during the COVID-19 pandemic" [2]. The emergence of this policy certainly has an impact on changes in 
the implementation of learning. From what is usually done offline (face-to-face), then it changes to online or other social media (google classroom, WhatsApp, google meet, etc.).

Online learning or social media is the right choice for the continuity of the learning process. This causes elementary students to be able to adapt to online learning and other social media [3]. Online learning is a type of learning that uses Internet media with accessibility, connectivity, flexibility, and the ability to generate various types of learning interactions [4]. This kind of learning during the situation of Covid-19 disease, is able to solve the problem of delays in students to acquire knowledge [5]. Thus, students must be encouraged to adapt to all the Internet network-based learning media. Then, the Internet network must be guaranteed not to have problems as a bridge between teachers/educators and students so that the learning process can be facilitated.

The conditions for online learning are not without speculation. Teachers find it increasingly difficult to take a closer look at the development of students' abilities and characteristics. Emotional awareness and understanding are not taught in schools [6]. Then students also felt the difficulty in addressing learning problems during this Covid-19 period. This condition causes parents to position themselves as teachers at home. During the pandemic, the role of supervision and parental attention to children in the online learning process is very important for the realization of optimal learning outcomes [7].

In this Covid-19 disease situation, parents have become the backbone of the learning process, and of course it has resulted in new situations faced by parents. Parents felt the change in the allocation of the family budget. It seems that there are additional costs to provide facilities, whether in the form of hardware such as computers or cellphones or the Internet network support devices in the form of data packages [1]. "The new economic conditions have forced parents to work harder than previous generations to provide for their families. This condition causes some parents to have less time to spend with their children when compared to the time their parents have" [8].

The problems faced by students increasingly show how crucial the position of parents to become future teachers of children during the Covid-19 pandemic. Hence, the roles of the parents should also be taken into consideration. "Every distance education policy must pay attention to the ability of parents in helping children learn. Especially for groups who are in poor socio-economic conditions who are most vulnerable, there needs to be various policies that support them" [9]. The employment and income levels of parents of temporary private workers vary widely. Consequently, the acceptance of this form of online learning in the Covid-19 situation has led to various speculations. Parents' readiness to accept and implement the learning process seems to vary according to the situation and conditions in the household.

There is a change in the learning process carried out online which results in changes in the readiness of parents to become teachers during the pandemic, encouraging researchers to further study the readiness of parents of elementary school students in Tenda Sub-district, Langke Rembong District, Manggarai Regency, in the academic year of 2020/2021. In Tenda, Langke Rembong District, Manggarai Regency, online learning in elementary schools has been carried out since March 19, 2020 until present time. Various situations and the readiness of parents are still the problems in optimizing the online learning process. This study will discuss a number of narratives, parental readiness, and strategies, and forms of collaboration between teachers/schools and parents in accompanying/managing children's learning time at home. 


\section{Methodology}

This research basically uses a qualitative design. Some of the stages that the researcher went through until the reporting were: 1) initial interviews with the parents of the elementary students at Tenda Elementary School. In this case, the survey was conducted in Tenda, Langke Rembong District, Manggarai Regency; 2) formulating research problems; 3) searching and evaluating the literature and previous studies; 4) determining the population and sample. The study population was all private and non-permanent workers - parents of elementary students in Manggarai Regency. The research sample was the parents of Tenda Elementary School who are private and non-permanent workers who were randomly selected from the population. 5) designing an interview instrument; 6) performing data analysis and 7) reporting and writing this article. The research subjects consisted of 10 people who were obtained from 5 parents of elementary school students who are private workers and 5 parents of temporary/non-permanent workers. The private workers are those who work in private institutions. Meanwhile, the temporary workers are workers who do not have work contract with their employers. In accordance with the research objectives, that is to reveal the readiness of parents to become teachers during the pandemic, the data of this study use information from interviews with the research subjects.

The data analysis of this research was carried out by following the process, namely data reduction. The process consisted of data selection, focusing the attention according to the research objectives, abstracting, and transforming data from the research site. Furthermore, the data were categorized data based on needs. The next activity was to carefully interpret the data. After the data processing stage has been carried out, the last stage was drawing a research conclusion.

\section{Result and Discussion}

\subsection{Results}

Some of the interview questions posed in this study to support the research data. All questions were answered by respondents. The results of the respondents' responses are as described below.

Table 1. The percentage of parents/guardians' answers regarding accompany and guide children in learning

\begin{tabular}{lll}
\hline \multicolumn{1}{c}{ Question } & Yes (\%) & No (\%) \\
\hline $\begin{array}{l}\text { During the Covid-19 pandemic, the children's education } \\
\text { process was no longer carried out in schools. Everything is }\end{array}$ & & \\
carried out in their homes. During the implementation of \\
the learning process, do parents/guardians accompany and \\
guide children to study at home?
\end{tabular}

From table 1 it is known that out of 10 respondents, $60 \%$ stated that parents/guardians assisted and guided children while studying at home, while $40 \%$ of respondents did not accompany and guide children while studying at home. This shows that the learning process 
carried out at home is still experiencing external obstacles. These constraints can be understood as part of the obstacles in achieving children's learning outcomes.

Table 2. The percentage of parents/guardian's answers who answered the questions in the initial table

\begin{tabular}{ccc}
\hline Question & Yes (\%) & No (\%) \\
\hline How often do you mentor/guide children while studying at home? & 66,67 & 33,33 \\
\hline
\end{tabular}

This question was given to the respondents who answered "Yes" in the first question. The Table 2 indicates that from 10 respondents, 66.67\% stated that parents/guardians often accompanied and guided children while studying at home, while $33.33 \%$ of respondents rarely accompanied and guided children while studying at home. This shows that the learning process carried out at home has not maximized the role of parents/guardians. Parents/guardians have not shown themselves as substitute teachers who can replace the role of school teachers in educating children.

Table 3. The percentage of parents/guardians' answers regarding home study schedules

\begin{tabular}{clc}
\hline Question & Yes (\%) & No (\%) \\
\hline During the Covid-19 pandemic, is there a study schedule? & 80 & 20 \\
\hline
\end{tabular}

Table 3 shows that out of 10 respondents, $80 \%$ stated that their parents/guardians made study schedules, while $20 \%$ stated that their parents/guardians did not make study schedules. The process of mentoring children to learn is adjusted to the tasks given by the teacher.

Table 4. The percentage of parents/guardians' answers regarding assisting your child to study at home

\begin{tabular}{cccc}
\hline Question & Both parents & Father/Mother & Never \\
\hline $\begin{array}{c}\text { Who supports your child to study at } \\
\text { home? }\end{array}$ & 0 & 60 & 40 \\
\hline
\end{tabular}

Table 4 reveals that out of 10 respondents, $0 \%$ stated that parents / guardians simultaneously assisted children to learn, while $60 \%$ stated that parents / guardians took turns assisting children to learn, and $40 \%$ of parents did not accompany children to learn. This shows that there are variations in the implementation of the learning process at home during the Covid19 pandemic. This situation illustrates that there are still a number of problems faced by parents and children in the process of mentoring and guiding children.

Table 5. The percentage of parents / guardians' answers regarding difficulties in assisting / guiding children's learning

\begin{tabular}{lcc}
\hline \multicolumn{1}{c}{ Question } & Yes & No \\
\hline $\begin{array}{l}\text { Do parents / guardians have difficulties in assisting / guiding } \\
\text { children to learn? }\end{array}$ & 100 & 0 \\
\hline
\end{tabular}


From Table 5 it is known that out of 10 respondents, $100 \%$ stated that parents/guardians had difficulty guiding/assisting children to learn, while none of them stated that they did not experience difficulties in accompanying/guiding children to learn. It shows that the parents have various difficulties. From the results of the follow-up interview on this question, the difficulty of parents in assisting/guiding children to learn is the difficulty of managing their time. In general, parents have good jobs, office work that must be done at home, as well as other obstacles at home. These obstacles include visiting guests at home, sudden family events that are forced to neglect the time for children's tutoring/mentoring.

What do the parents/guardians do to monitor children's learning?

Respondents' answers to this question do not differ significantly. What respondents do in monitoring children's learning includes: accompanying by checking the child's homework/assignments that have not been completed, accompanying children by monitoring learning progress by giving assignments as additional exercises to children, then presenting their work. Another form of parental / guardian monitoring of children's learning as expressed by several respondents is in the form of checking textbooks, other equipment needed in learning, responding to learning needs, helping to check and correct the children's answers of the assignment.

\section{Discussion}

The shift in the provision of the learning process during the Covid-19 pandemic has been running, which is being carried out at home. At the beginning of the Covid-19 pandemic, there were various speculations. Rejection of changes in student learning models came from various parties, especially parents/guardians. Parental rejection is not without causes. As a matter of fact, being a teacher is not an undemanding job. Teachers who go through the educational process still experience obstacles in educating their children. Taking into account Covid-19, which has not shown an end, the learning process is carried out from the homes/residences of students. This new reality of the education process seems to require the cooperation of teachers and parents/guardians, especially in accompanying and guiding children to learn.

[10] explains that there are several efforts that should be considered in assisting children during a pandemic. Those are: (1) create a study schedule and rules together. (2) help children with activity ideas if the child is unsure about finding activities. (3) build positive relationships and always ask positively, especially when children start an activity. (4) remind children about the time they have for an activity, and (5) parents need to reflect on the work that has been completed with the children.

This shows that the work of parents/guardians must start with planning, then proceed with implementation, process monitoring, and student learning evaluation. Implementation is of course related to mentoring/guiding children in the learning process. Supervision of parents/guardians in the learning process is needed by the children. Parental involvement must be realized to ensure the implementation of the education process at home. Some of the findings from research point out the inadequacy in roles of parents/guardians in accompanying/guiding children to study at home during the Covid-19 pandemic. There are still some children without parental / guardian guidance. This shows that children do not experience the education process at home. These situations will undeniably have an impact on children's achievement. Besides, 
the child also does not gain sufficient knowledge as intended in the lesson objectives. The negative impact of the absence of a process and monitoring of child development is that children are not able to optimally move to the next content of the lesson/subject.

In general, parents/guardians have difficulty guiding and accompanying children at home. After going through interviews about parental difficulties, several causes were found, such as: (1) they do not have the experience of teaching like a teacher, (2) they find it difficult to arrange a schedule for guiding children, (3) children cannot perceive their parents/guardians as teachers, (4) children rarely follow orders from parents/guardians to complete school work, (5) children are hesitant to follow the learning schedule made by parents/guardians. Some of the findings above show that the psychological aspects of parents/guardians are the cause of the less optimal learning process at home during the pandemic. Anxiety, doubt, fear, and lack of experience of the parents make it difficult for the process of guiding and assisting children at home.

This is different from the findings of research conducted by [11], which stated that parents were overwhelmed in holding back emotions caused by children being difficult to study at home, difficulties in terms of limitations of cellphone and laptop media because parents need to allocate time to deal with more than one child. Additionally, the difficulty to provide internet quotas was also experienced by the parents; most of the assignments used online platforms and the teacher gave assignments too often. The parents feel burdened when the child is unwilling to study, and lack patience when the child prefers to play games on cell phone rather than study.

Several other findings related to complaints from parents/guardians regarding the learning process during this pandemic, namely it is difficult to arrange time to be a companion/teacher for children, difficult to explain subject matter to children, limited time for children, parents experience limited time and knowledge in monitoring the development of children's characteristics during the learning process. From some of these findings, it can be believed that children have difficulty gaining knowledge, and children's learning experience is reduced. This finding illustrates that parent do not fully consider themselves as teachers.

Findings of anxiety, doubt, fear, and lack of experience strengthen the hope that there is a need for education/training efforts for parents. Parents experiencing obstacles are not without cause. Parents need experience with adequate attitudes, knowledge and skills in educating children. In addition, parents have mental toughness in accompanying their children through their lives. This is reinforced by the findings of research conducted by [12], which states that the importance of parental involvement in accompanying young children in reading activity and accompanying in every activity at home.

In addition, [9] emphasized that in situations where schools are closed, it is very important to prepare adequate reading materials for students and intensive parental involvement. Any distance education policy must take into account the ability of parents to help their children learn. Especially for groups who are in poor socio-economic conditions who are in the most vulnerable position, there needs to be various policies that support them. Thus, parents need to be equipped with pedagogic, social and personality knowledge as well as child counseling with the aim that children do not experience differences in the educational process at home and at school.

\section{Acknowledgment}

We would like to express our gratitude to UNIKA Santu Paulus Ruteng for funding this research. Special thanks to all the respondents involved in this study who have helped with the data. 


\section{References}

[1] Saleh, A. M. 2020. Problematika Kebijakan Pendidikan Di Tengah Pandemi Dan Dampaknya Terhadap Proses Pembelajaran Di Indonesia. Jurnal Pendidikan, 2(2), 24-24.

[2] Goldschmidt, K., \& Msn, P. D. (2020). The COVID-19 pandemic: Technology use to support the wellbeing of children. Journal of Pediatric Nursing, xxxx, 3-5.

[3] Nuryanti, A. dkk 2021. Adaptasi Siswa Terhadap Proses Pembelajaran Sebagai Bentuk Upaya Mitigasi Selama Pandemi Covid-19. Jurnal Elementary, 4(1), 60-65. http://journal.ummat.ac.id/index.php/elementary

[4] Sadikin, A., \& Hamidah, A. (2020). Pembelajaran Daring di Tengah Wabah Covid-19. Biodik, 6(2), 109-119. https://doi.org/10.22437/bio.v6i2.9759

[5] Herliandry, L. D. dkk., 2020. Pembelajaran Pada Masa Pandemi Covid-19. Jurnal Teknologi Pendidikan. 22(1), 65-70.

[6] Tihnike D. 2018. Fungsi Keluarga Dalam Membentuk Kecerdasan Emosional Pada Anak. PANCAWAHANA: Jurnal Studi Islam. 13(2), 80-92

[7] Wardhani, Tsaniya Zahra Yuthika \& Krisnani, Hetty. 2020. Optimalisasi Peran Pengawasan Orang Tua Dalam Pelaksanaan Sekolah Online Di Masa Pandemi Covid-19. Prosiding Penelitian dan Pengabdian Kepada Masyarakat (48-59), Vol 7, No: 1, 2020.

[8] Goleman, Daniel. 1999. Kecerdasan Emosional. (Terj. Haermaya). Jakarta: PT Gramedia.

[9] Brossard, Matt; Cardoso, Manuel; Kamei, Akito; Mishra, Sakshi; Mizunoya, Suguru; \& Reuge, Nicolas. 2020. Parental Engagement in Children's Learning. UNICEF. Sumber: https://www.unicef-irc.org/publications/pdf/IRB\%202020-09\%20CL.pdf

[10] Diana, Rachmy. 2020. Peran Orang Tua Dalam Pendidikan Anak di Era Pandemic COVID-19. Sumber: https://s3ppi.umy.ac.id/wpcontent/uploads/2020/06/Dr.-Rachmy-Dian

[11] Mastoah Imas \& Zulaela. 2020. Kendala Orang Tua Dalam Mendampingi Anak Belajar Pada Masa Covid 19 Di Kota Serang. Jurnal Pendidikan Anak Usia Dini, 5 (9) 121-128

[12] Nicole Hayes, Donna C Berthelsen, Jan M Nicholson \& Sue Walker (2018) Trajectories of parental involvement in home learning activities across the early years: associations with sociodemographic characteristics and children's learning outcomes, Early Child Development and Care, 188:10, 1405-1418, DOI: 10.1080/03004430.2016.1262362

[13] Kemendikbud. 2020. Kebijakan Kemendikbud Dimasa Pandemi. Tersedia [https://gtk.kemdikbud.go.id/read-news/kebijakan-kemendikbud-di-masa-pandemi] diadaptasi pada tanggal 1 Maret 2021. 